\title{
Chemistry Textbook Editing: A Cross-disciplinary Case Study
}

\author{
Noemih Sá Oliveira, Susan Bruna Carneiro Aragão \\ Sistema Mackenzie de Ensino - Mackenzie \\ Presbyterian Institute-Brazil
}

\begin{abstract}
This paper presents a case study about the development of a cross-disciplinary propose for preprimary, primary and secondary private school textbooks and course materials based on a JudeoChristian educational worldview. A private Brazilian system of education, Sistema Mackenzie de Ensino (SME), located in São Paulo-Brazil, developed this proposal. SME is reasoned in a worldview, which considers ontology precedes epistemology to try to reach a more integrated perception, comprehension, and reflection of the study object. A crossdisciplinary team of teachers gathered to elaborate a critical basis for producing and reviewing the textbooks and course materials. This rational basis considered the guidelines of the National Brazilian Curriculum Parameters and academic researches. Sistema Mackenzie de Ensino has already published around 700 school textbooks and course materials (student and teacher textbooks, teacher manuals, workbooks) since 2009, and is currently used in about 350 schools, 70,000 students, in 21 out of 24 Brazilian States. As an example, this case study will show the production of a chapter of the Chemistry textbook for 2nd year of Upper secondary level of education, which deals with electrochemical contents, arguing about why ontology preceding epistemology provides a more integrated perception, comprehension, and reflection of the study of Chemistry.
\end{abstract}

\section{Introduction}

A private Brazilian system of Education, Sistema Mackenzie de Ensino (SME), elaborated textbooks and course materials with the aim to promote an emphasis on practical, scientific, ethical and moral knowledge in education.

SME was implemented in partnership with Mackenzie Presbyterian University (MPU), and both are part of Mackenzie Presbyterian Institute (MPI), a private and philanthropic educational institute located at São Paulo - Brazil. It has educational programs to pre-primary, primary, secondary and university students.

Mackenzie Presbyterian Institute (MPU) is a 147year-old private, non-profit, non-profit educational institution. The history of the institute dates from the 19th century, when Presbyterian missionaries founded, in São Paulo, the American School. The foundation of the new school represented a turning point in Brazil. The school introduced a series of pioneering and innovative pedagogical and social practices. Among them, the end of racial discrimination in admissions (legally authorized by the government until then), the creation of mixed gender classes and the abolition of physical punishments [1]. Throughout its existence, it has implemented courses with the objective of covering new areas of knowledge and accompanying the evolution of society with intense participation in the community. Mackenzie Presbyterian Institute (MPU) has become recognized by tradition, pioneering and innovation in education, which enabled it to reach the position of one of the renowned educational institutions that contribute most to the scientific and academic development of the country. As a denominational entity, it promotes the development of citizens who understand solidarity as an indispensable element for today. Since its foundation, the Institution, an agent of a series of pedagogical innovations, accompanies and influences the educational scenario in the country, having as one of its main concerns the ideal of educating citizens with capacity for discernment, with criteria and conditions for reading of the world in which they live and able to intervene in the society of which they are part.

SME is the department of MPI responsible for editing and publishing textbooks and course materials for basic education.

In Brazil, basic education consists of three stages [2]:

- ISCED 0 - Creche e Pré-escola (Pre-primary level of education - from 3 years old)

- ISCED 1 - Ensino fundamental (Primary level of education - 1 st to 5 th year or equivalent)

- ISCED 2 - Ensino fundamental (Lower secondary level of education - 6th to 9th year or equivalent)

- ISCED 3 - Ensino médio (Upper secondary level of education - 1 st to 3 th year or equivalent)

To teach for children with 0-10 years, the teacher must have a pedagogy degree, and in class, there is just one teacher for all school subjects. To teach for children with 11-17 years old, the teacher must be a specialist in one school subject and have a pedagogy complement. In class, there is one teacher to each school subjects.

\section{Editing textbooks}

As said by Woll, "publishers generally start companies because of a compelling idea or concept they have" [3]. As a philanthropic institute, Mackenzie Presbyterian Institute decision to make, 
edit and publish schoolbooks are les s motivated by the profit than to this compelling idea that Brazilian schools need an improvement in their schoolbooks.

Textbooks on Brazil are one of the most lucrative business on the country since the president Getúlio Vargas, in 1937, created the National Book Institute - the genesis to the National School Book Program, that, since 1985 until today it is a program that already has billions in investment. According to Figueiredo, between 1994 and 2005, the Brazilian government invested precisely $\mathrm{R} \$ 3,8$ billion reais (around US\$ 1 billion) in this program [4].

The program started aligned with international policies that are specifically designed to assist the third world: the idea was that schoolbooks would make public school on Brazil better [4]. So, the textbook production started with very rudimentary editing and publishing know-how, that, among the first challenges, have to deal with [4]:

1. The dimension of the country;

2. The quality of the schoolbooks content;

3 . The editing and publishing process itself;

4. The rising of school systems.

About the dimension of the country, the challenge was, and until nowadays is, to have an efficient logistics system that is capable of delivering the schoolbooks to all public schools on Brazil, some of them located on very precarity regions with few infrastructures as roads and security. About the quality of the textbooks content, as the program was a national one, first public Universities as Universidade Federal de Minas Gerais (UFMG), Universidade de São Paulo (USP), Universidade Federal de Pernambuco (UFPE) and Universidade Estadual de São Paulo (Unesp) became responsible to develop school content for the textbooks that are bought by the government [4]. One of the most significant problems was that there was no agreement between teachers with some of the authors' propositions to national education [4]. The Brazilian government asked, then, the universities researchers to elaborate National Curriculum Parameters to public and private schools, and individual editors and publishers could develop books according to those parameters to the government buy those textbooks that fulfill better the parameters.

Until today disagreement between authors continue, and besides, the opportunity to have the government as buyer started very aggressive marketing among editors and publishers [4]. Nonetheless, while all this discussion about who writes the better schoolbook according to National Curriculum Parameters happened, the teachers who are supposed to use the books were not take into account. On this context, a very peculiar phenomenon raised in school publishing history on Brazil: the private "School systems" (Sistema de Ensino).
Initially, those private "School systems" were structured by high school teachers that printed their school activities and materials to help students to succeed on public universities admissions tests, the vestibular. As the public universities' admissions tests are standard to all country, those teachers started to commercialized their materials adding assignments, lessons plans, and even school management protocols to other schools, even the public ones, that wanted to guarantee public universities admissions tests' approval. All this package with printed school activities and materials, added to assignments, lessons plans, and school management protocols became the "School systems" (Sistema de Ensino) [5].

About this phenomenon, one auditor of Brazil's Court of Auditors have said: "Teaching quality is not a product that one can sell apart from good teachers and good teaching and learning conditions. Those who affirm that the "School Systems" are better to prepare students to the public universities admissions tests must not be listened to because, in the way I see, school education must not be a process to a singular event, but to human integrity improvement" [6].

Considered all this, still, the educational scenario in Brazil is alarming. On the last Programme for International Student Assessment - Pisa (2015/2016), Brazil is among the last ten in science rank (63) and mathematics rank (65). In reading, Brazil is in the 59th position [7]. According to one program that researches on literacy in Brazil, from 2001 until 2018, Brazil proficiency is on $7,4 \%$ practically without no variation [8].

Textbooks could be strategic to a country that does not have reading proficiency ever since it could be the first book to open the door to other books that are not textbooks only. This belief was by the rise of MPI's decision to make, edit and publish schoolbooks.

Having its concept of what is the world, the others and God, and being philanthropic and a private (not public) institution, MPI has the legal right to propose an editorial line that could be more and even could discuss some of the National Curriculum Parameters. With this possibility, MPI structured its own "School System" to, first, its four schools (Mackenzie São Paulo, Mackenzie Tamboré, Mackenzie Brasília, Mackenzie Palmas), redesign School System concept not as printed school activities and materials, added to assignments, lessons plans, and school management protocols but as:

1. Textbooks made, edited and published according to MPI's editorial line;

2. School online platform, with games, school ebooks, e-books with extra materials, video classes,

newsletter, teachers' forum, school community online forum, among other online resources;

3 . Teacher's continuous training. 
About MPI's editorial line, MPI's compelling idea started with Martha MacCullough [9] thesis that to have a systematic educational practice the better way it is not to establish a standard methodology but to gather educators that share the same educational philosophy. This philosophy is the basis for a learning model that is a reference to educational practice.

According to René Descartes in his famous book Discourse on Method [10], "I think, therefore I am." That statement was a start to philosophers develop the perception that epistemology precedes ontology. This worldview lasts long. In education, this worldview promoted the emphasis on scientific knowledge. In contrast, there are also other worldviews with a millenarian history, such as a Judeo-Christian view, which considers ontology precedes epistemology. Immanuel Kant, years later Descartes stated the idea of "We find existing in mind a priori, the pure form of sensuous intuitions in general, in which all the manifold content of the phenomenal world is arranged and viewed under certain relations." [11]. So, for Kant, there is a phenomenal world, a mind, and a view, which he called Weltanschauung. Certain relations throughout we see the world form this view; a worldview, therefore.

For Friedrich Nietzsche, if everything we have from the world is a view, so this view is trust worthier than the phenomenal world we do not immediately know. Then, what really matters for Nietzsche is our "movable host of metaphors, metonymies, and anthropomorphisms: in short, a sum of human relations which have been poetically and rhetorically intensified, transferred, and embellished, and which, after long usage, seem to a people to be fixed, canonical, and binding." [12].

Thus, although I do not know a city, it could mean, in practice, that it does not exist? Although the non-existence of the city is logical and reasonable, it exists.

Analyzing these ideas, a contemporary philosopher J. Sire [13] stated that if epistemology precedes ontology, thinking is before existing. However, the opposite is also considerable: if ontology precedes epistemology, then existing is before thinking. The second one is the

Judeo-Christian culture paradigm. JudeoChristian thinkers, as James Orr and Abraham Kuyper, also recognized that there is something such as a worldview. Nonetheless, this Judeo-Christian worldview is settled on the paradigm in which ontology precedes epistemology.

For this paper, it is presumed a Judeo-Christian worldview concept. According to Albert M. Wolters "a worldview, even when it is half unconscious and unarticulated, functions like a compass or a roadmap. It orients us in the world at large, gives us a sense of what is up and what is down, what is right and what is wrong in the confusion of events and phenomena that confronts us." For him, yet: "we are inescapably creatures with responsibility which by nature are incapable of holding purely arbitrary opinions or making entirely unprincipled decisions. We need some creed to live by, some map by which to chart our course. The need for a guiding perspective is basic to human life, perhaps more basic than food or sex" [14].

For Sire, "worldview is a commitment, a fundamental orientation of the heart, which can be expressed as a story or as a set of assumptions (assumptions that may be true, partially true or totally false) that we hold (consciously or subconsciously, consistently or not) about basic constitution of reality, and which provides the foundation upon which we live, move, and exist." [15].

Thus, worldview is not just a cognitive aspect. It is an ontological feature of human nature. Educational initiatives, though, would be the inevitable consequence of this ontological feature.

MacCullough [9] developed a Judeo-Christian educational initiative. She adopted the concept of interactive learning "viewed as including inside and outside factors as a unified whole in the process of learning." She proposes that "in addition to the existence of an outside reality and external knowledge, the concept that the human innate capacity for processing and developing meanings and understandings is an essential element in learning. Inside and outside factors matter. Understanding the concept of the interactive learner is the starting point for the development of pedagogical (teaching) implications". She also presents a cognitive interactive learning model [16].

\subsection{Educational Practice}

To transform MPI Judeo-Christian worldview and the SME Cognitive-interactive learning model in practice, first as a book and then as a teaching and learning process, MPI develop SME's framework, that consists on conduct the reader/student into four steps during the reading/learning process: theme, analysis, conceptualization and evaluation [17].

The theme is the fundamental question. SME's editing team elaborates it by the analysis of school contents through the Judeo-Christian worldview lens. SME's editing team thinks the school content considering Herman Dooyeweerd' modal aspects [18] to systematize this process.

Considering Herman Dooyeweerd's modal aspects, the SME's team localize the modal aspect in the study but do not enclosure reality to this aspect only. Considering all modal elements, what is the importance of one school content? How is this school content related to other modal aspects? 


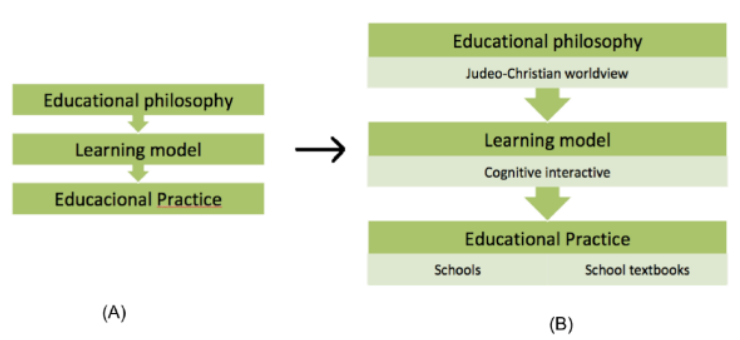

Figure 1. (A) McCullough's thesis (B) MPI's editorial line idea

\begin{tabular}{|c|c|c|c|c|}
\hline Modal aspects & \multicolumn{4}{|c|}{ Range } \\
\hline Faith & \multirow{15}{*}{$\sum_{\substack{k \\
\Sigma}}^{z}$} & \multirow{15}{*}{$\sum_{\sum_{\alpha}^{\infty}}^{n}$} & \multirow{15}{*}{ 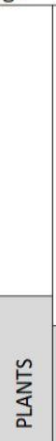 } & \\
\hline Ethical & & & & \\
\hline Juridical & & & & \\
\hline Aesthetic & & & & \\
\hline Economic & & & & \\
\hline Social & & & & \\
\hline Lingual & & & & \\
\hline Historical & & & & \\
\hline Analytical & & & & \\
\hline Psychical & & & & \\
\hline Biological & & & & \\
\hline Physical & & & & \multirow{4}{*}{$\begin{array}{l}\text { 员 } \\
\stackrel{\text { I }}{1}\end{array}$} \\
\hline Kinematic & & & & \\
\hline Spatial & & & & \\
\hline Arithmetical & & & & \\
\hline
\end{tabular}

Figure 2. Herman Dooyeweerd's modal aspects

Further, in this kind of exercise the fundamental question is elaborated.

Once the fundamental question is founded and presented to the reader/student, then, he/she starts the analysis process of understanding the small parts of the problem.

On this stage, the reader/student starts with his/her perception on the theme, and then gradually have their first perception analyzed and problematized, what impels him or her to formulate new ways to think and talk; generally speaking, new ways of representing his or her thoughts about the subject.

Then, the book (the author) or the teacher presents to the student how scientists perceived, in the history of science, this fundamental question; how it was thought and represented by scientists/thinkers across the years. On this moment, scientific concepts are established to the reader/student.

After those steps, the reader/student will be confronted to his/her first perception related to the fundamental question. Moreover, now there is a new problem: after all he/she had learned about this particular aspect of the world, his/her perception of the fundamental question is still the same?

SME's framework (see Figure 3), then, represents SME's educational philosophy, and Cognitiveinteractive model, since all those steps are related with the cognitive model of David Ausubel and his Meaningful Learning Theory that states rote, representational, and meaningful learning as part of acquisition and retention of knowledge [19].

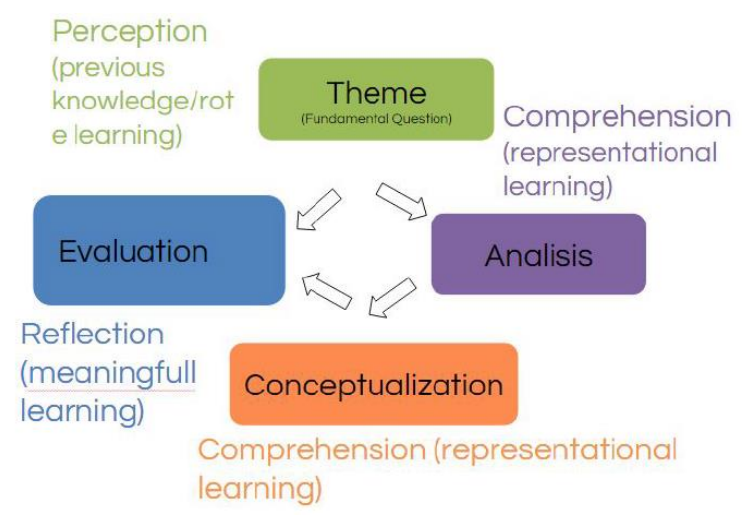

Figure 3. SME's framework

\subsection{MPI's Editorial Line and SME's Books Publication}

MPI's expanded SME to other schools besides its four schools, first by the textbooks' publication, only. To do so, SME must have a team of multidisciplinary authors and editors, copyrights team, graphic designers, copy desk team, among other groups, to transform its editorial line on books. Nowadays, more than 200 private schools adopted SME materials, with its books, platform access, and teacher education program.

\section{Methodology - A worldview in Science}

As explained, SME's Cognitive-Interactionist model is reasoned in a worldview which considers ontology precedes epistemology. Thus, it takes different fields of knowledge to think about the same existing factor, to try to reach a more integrated perception, comprehension and reflection as possible of the object. According to this worldview, science is an investigative practice on the natural phenomena [20]. Due to the human curiosity to understand the reality, humans develop science amid the search of explanations on the natural world. By observing these phenomena, humanity can glimpse God's order and laws, and the beauty of his creation [21].

Considering that in reality there are observable regularities that can be described by scientific laws, natural laws, or theories. Some regularities are quantitatively described (within small error limits), while others are considered only when a large number of cases are examined together, i.e., when a large sample is taken for analysis. All scientists believe in the existence of such regularities. In the Christian view of science, we understand that "the regularities represent God's commitments and actions" [22], and it is through them that we observe the order and rule of God. 
In every scientific enterprise, it is necessary to clip the created reality so just a short piece can be investigated. In this process, a single facet of a multifaceted existence is abstracted. From this abstraction, an analysis is performed, and then synthesis is elaborated, that is, an explanation for the phenomenon. Moreover, what does that mean? It means that the synthesis developed on this clipping describes only a "piece" of reality, and its conclusions do not constitute an explanation of all things that exist [23]. Therefore, in Science, care must be taken not to confuse scientific theories with reality itself, thus avoiding scientism - the excessive belief in the power of scientific and technological knowledge as the only absolute truth [21]. In this view of science, that ontology precedes epistemology, it is assumed that the created reality does not depend on the process through which we acquire our perception of it.

According to Spears, "Things exist and continue to exist regardless of how we discover them. (...) We do not create new knowledge, but we develop methods that enable our students and us to have access to the real universe." [24] For students to develop this view of science, SME considered three educational approaches: the history and philosophy of science, the contextualization of scientific concepts, and inquiry. The Brazilian Curricular

Parameters [25] recommends this set of approaches - the history and philosophy of science, the contextualization, and inquiry. We believe they can enable science education with the aim of scientific literacy [26].

The approach history and philosophy of science can provide the development of a vision of science in line to the Judeo-Christian worldview, which presupposes that science is developed non-linearly, being part of a collective process of elaborating ideas, breaking with distorted visions as "science is an absolute truth" [27] [28] [29] [30] [31]. This approach considers historical narratives to introduce scientific knowledge showing how science is developed, immersing the students in a specific time and space [32].

The contextualization of scientific concepts can provide meaningful learning as it relates to the students' daily life to the scientific knowledge studied in the classroom [33] [34].

Inquiry based-learning starts with a questionproblem, related to a facet of reality, and promotes the study of scientific concepts by searching for possible solutions to the problem. During this process, students formulate hypotheses, research and organize information, elaborate conclusions in the light of science and can develop high-order cognitive skills [35] [36] [37].

\subsection{Chemistry textbook and course materials - A case study}

As an example of this worldview, we will present the case study of the development of Chemistry textbooks and course materials. Therefore, a crossdisciplinary team of teachers was necessary to elaborate a critical basis for producing and reviewing the textbooks and course materials. This critical basis also considered the guidelines of the National

Brazilian Curriculum Parameters and academic researches. Each textbook has four thematic units, which sub-themes were divided into three chapters. It was published among 2009 and 2017 and is currently used in about 250 schools, 50000 students, in 21 out of 24 Brazilian States.

To develop textbooks and course materials and accomplish the Brazilian National Curriculum for High School from a Judeo-Christian perspective, the SME elaborated the schoolbooks and course materials in three stages: planning, content structuring, and work production.

In this case study, Chemistry textbooks and course materials for K-11 students were planned, structured and produced as following [38].

\subsection{Planning Chemistry textbooks and course materials}

The planning stage for Chemistry textbooks and course materials consisted of:

- selection of a cross-disciplinary team (chemistry researchers, chemistry teachers, educationalists, philosophers, theologians, editors, and graphic designers) to elaborate Chemistry textbooks and course materials according to SME pedagogical proposal;

- analysis of the Brazilian National Curriculum Parameters;

- academic research about history and philosophy of science; contextualization, inquiry, and nature of science;

- research on specialized journals in chemistry education;

- analysis of college entrance exams.

\subsection{Structuring Chemistry textbooks and course materials}

Chemistry textbooks are structured with thematic units; four units per school year. Each unit has three chapters. From the unit theme, each chapter brings integration among:

- practical knowledge - inquiry activities, researches, exercises, and concept maps;

- scientific knowledge - chemistry content, scientific language, nature of science, history and philosophy aspects; 
- ethical and moral knowledge - ethical-scientific debates, argumentation, different perspectives of the same chemistry content.

\subsection{Producing Chemistry textbooks and course materials}

The production of textbook and course materials stage was divided in five parts:

1. writing original texts;

2. collaborative reading and analyzes of original texts;

3. rewriting the original texts;

4. final version assessment;

5. editing and publishing.

The team of chemistry teachers and researchers performed parts 1 and 3, and the cross-disciplinary group performed parts 2,4 , and 5 .

\section{Results}

As a result of the SME pedagogical proposal initiative published around 700 school textbooks and course materials up to 2017. As an example, this case study will consider the fourth unit, chapter 10 , of Chemistry textbook for K-11 students (16 years old) about Electrochemistry [39].

This chapter contents:

- practical knowledge - analyzing different perspectives about the understanding of electricity concept (Greek philosophers, Benjamin Franklin, Luigi Galvani, Alessandro Volta, Michael Faraday ideas);

- understanding corrosion as an electrochemical reaction, electrochemical reaction analysis, concept map about the electrochemical reaction;

- scientific knowledge - corrosion in everyday life, electrical current, oxidation-reduction reaction, reduction potential, spontaneous and nonspontaneous electrochemical reactions, oxidizing and reducing agents, electrolysis, batteries;

- ethical and moral knowledge - the discussion of the concept that "does life mean motion?".

Applying the SME pedagogical proposal, the chapter begins with the famous Mary W. Shelley's work "Frankenstein", inquiring the reader about the idea of some corpse being electrocuted and becoming alive. The fundamental question of the chapter is: life means motion? If so, electrical phenomena can "transfer" life to inanimate things or even corpses?

Then, working with history and philosophy of science approach, the writer presents the curious phenomenon observed by Plato, in his "Timaeus": some inanimate objects gain motion in the presence of some material, such as amber or magnetite.

Charles F. C. Dufay elaborated the idea of two types of electricity vitreous and resinous. Benjamin
Franklin studied the vastly lightning phenomenon and described his thoughts on experiments and observations on electricity. Luigi A. Galvani studied some animals such as moray eel and developed the idea of "animal electricity". His book "De viribus electricitatis in motu musculari commentarius" Commentary on the Effects of Electricity on Muscular Motion inspired his nephew Giovanni Aldini who conducted electrical experiments with a corpse that inspired Shelley's story [40].

After these ideas, the writer presents another point of view about electricity: Alessandro Volta's studies.

Volta confronted Galvani's idea published in the Journal of Philosophical Transactions about "animal electricity" stating that electricity is due to both metals involved by a salty liquid. Volta developed his idea of constructing a pile named "battery."

The writer relates Volta's work with the current batteries developing the concepts of oxidationreduction reaction, reduction potential, spontaneous and non-spontaneous electrochemical reactions, oxidizing and reducing agents, and electrolysis.

While all this scientific knowledge is discussed, the text is interspersed with the practical knowledge (electrochemical reaction analysis and concept map), and contextualized approach is applied by the discussion about how electricity and technological development impact society and environment. The ethical and moral knowledge is centered on the fundamental question: "does life mean motion?". This ontological question started years of studies, development of scientific and practical knowledge, even though, as an ontological question, remains updated.

\section{Why ontology preceding epistemology provides a more integrated perception, comprehension, and reflection of the study of Chemistry?}

SME considered a Judeo-Christian worldview to elaborate textbooks and course materials. According to this view, ontology precedes epistemology. So, science is an investigative practice on the natural phenomena. Through science, we can abstract a single part of reality, analyze it and synthesize an explanation about this phenomenon.

Applying this view on Chemistry textbooks and course materials, SME provided students understanding about electrochemical concepts, and also the understanding of how scientific knowledge is elaborated. To do this, SME used the historical narrative about the development of electrochemistry. This approach provided the development of various aspects of the nature of science, such as empirical, inferential, creative, theory-driven, tentative, the myth of "the scientific method", scientific theories, 


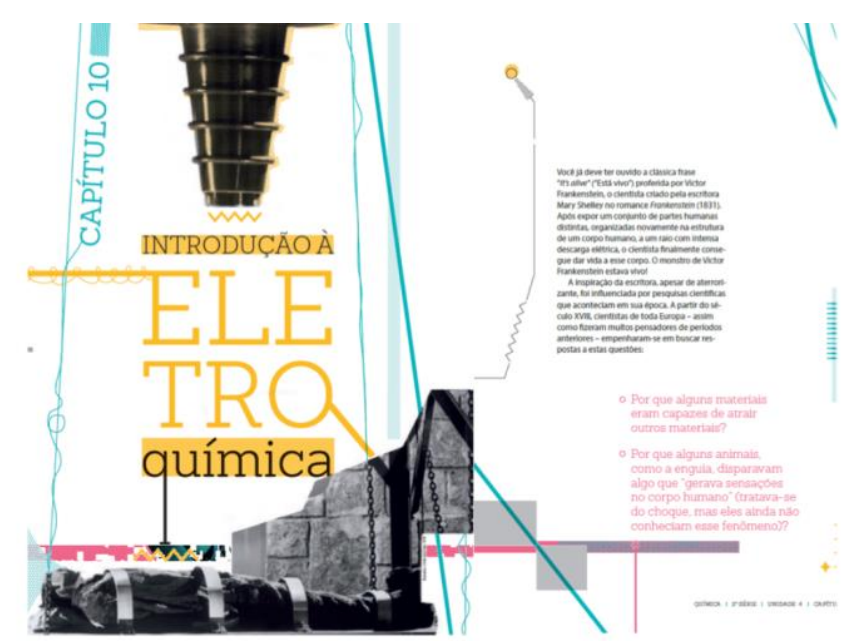

Figure 4. SME Chemistry Textbook - Chapter 10 - Introduction of Electrochemistry - Presenting the theme: "Does life mean motion?"

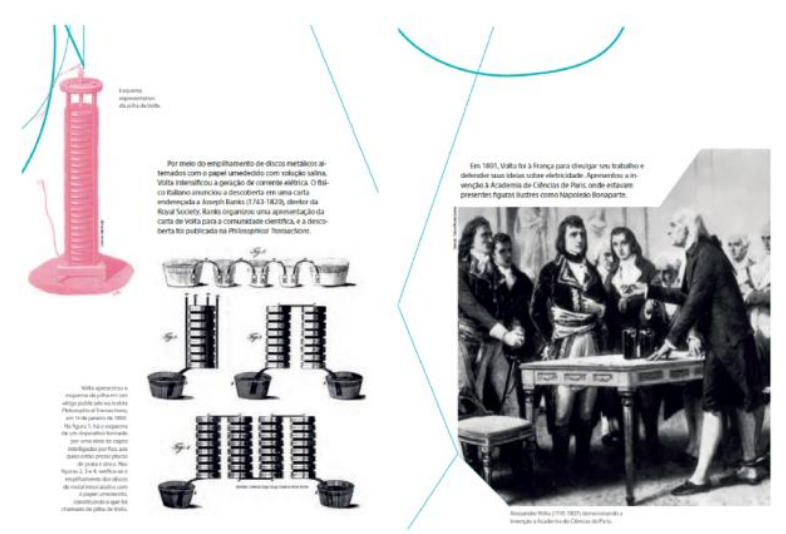

Figure 5. Practical knowledge
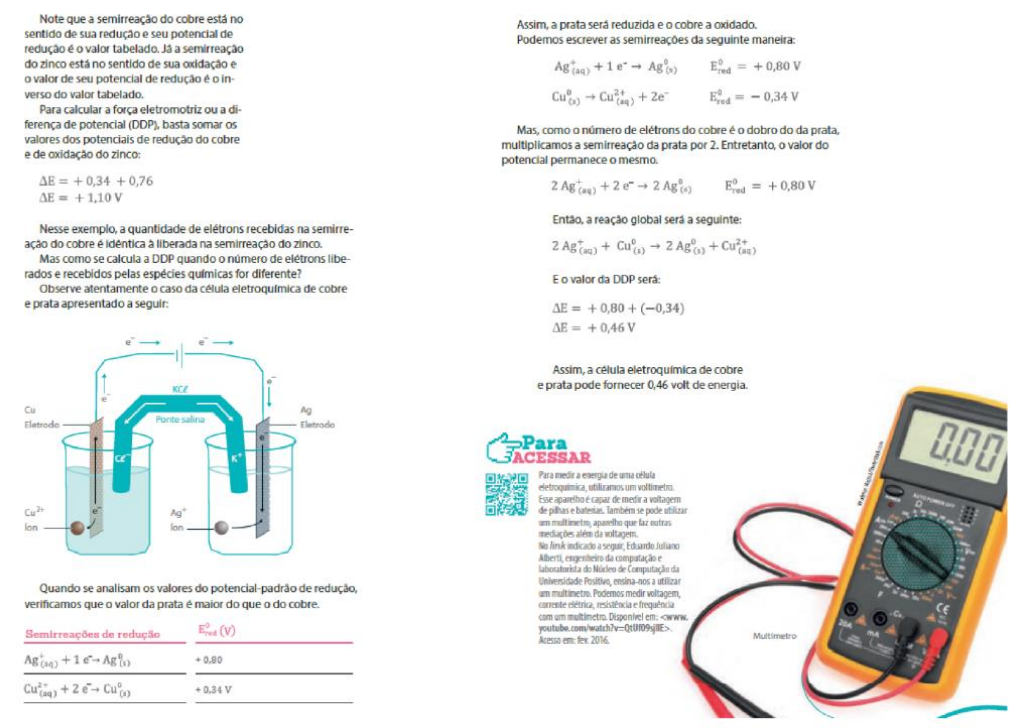

Figure 6. Scientific knowledge 
scientific laws, Social dimensions of science, social and cultural embeddedness of science [41].

The chapter begins showing the experiments carried out from the observations of the electrical phenomena. Charles F. C. Dufay and Benjamin Franklin reproduced some of them. After that, presents Luigi Galvani's experiments related to the "animal electricity". From they have discovered that electricity could be transmitted, like a fluid, from one body to another, Galvani and others inferred that electricity was the cause the animal contraction. Italian physician was so eager to prove his ideas that he did not take into account the contractions produced by a mere touch of metal. So, he conducted experiments carefully, seeking evidence that would prove his ideas. Many considered the idea of "animal electricity". Despite this widespread acceptance, Alessandro Volta developed another hypothesis to explain the same phenomenon. He was incredibly creative in developing a pile of metals sandwiched with a cloth bathed in saline, naming his apparatus as "battery", the name we use to this day. The chapter discusses this scientific controversy showing that Galvani was a physician so, a frog was the objective of his study, while Volta, a physicist, the metals. Then their view about the same phenomenon was different. The chapter discusses this scientific controversy showing that Galvani was a physician so, a frog was the objective of his study, while Volta, a physicist, then, their view about the same phenomenon were different. During the discussion, scientific concepts were developed such as the nature of electricity, transmission, and materials that conduct electricity. Volta became so famous that he met Napoleon to show his invention.

Thus, when the most specific concepts of oxidoreduction reactions were presented, such as corrosion, electrical current, oxidation-reduction reaction, reduction potential, spontaneous and nonspontaneous electrochemical reactions, oxidizing and reducing agents, electrolysis, students will be already immersed themselves in the context of electrochemistry, avoiding the fragmentation of chemical concepts, reductionism and a distorted view of science. Finally, the ethical and moral aspects of the discussion of the initial problem issue: "does life mean motion?".

So, through the SME's Cognitive-Interactionist Model, from the chapter theme, students were able to perceive natural electrical phenomena. Then, the analysis provided the comprehension of the phenomena, and in the end, they were able to reflect on, now with a new perception, concepts related to this during the study of Electrochemistry.

\section{Conclusion and Considerations}

SME pedagogical proposal, placing ontology before epistemology provided a rich scenario to develop cross-disciplinary discussion to elaborate textbooks and course materials. It also accomplished the idea of developing textbooks and course materials with a more complex approach to school content avoiding reductionism. Besides, the completeness reaches different types of students, not just the one who likes hard-science, but also who loves literature, history, philosophy, benefiting the teaching-learning process.

Moreover, SME produces textbooks idealizing them as instructional resources for students to read as a book and to meet national curricular standards. Nevertheless, in Brazilian classrooms, due to the low quality of teacher education programs and lack of content knowledge, "textbooks become the curriculum and determine, to a much larger extent than desired by science educators, what is taught and learned about science in these classrooms" [42]. To promote a better quality of learning process, SME provides a teacher education program.

Another significant challenge of this project is its reproducibility because it involves high cost in hiring a cross-disciplinary team and a large production time frame. It was possible because a philanthropic initiative ran it. Nevertheless, it is essential for the development of other educational efforts with the same worldview collaborate with works.

\section{References}

[1] Mackenzie. Portal Educational, http://portal.mackenzie.br/en/ instituto/coi/institutional/about-mpu/, (Access date: 01 July 2018).

[2] OECD. Education at a Glance 2011. OECD Indicators, Country note - Brazil, 2011.http://dx.doi.org/10.1787/eag-2011en, (Access date: 20 October 2018).

[3] T. Woll. Publishing for profit: Successful Bottom-Line Management for Book Publishers. Chicago Review Press, USA, 2014, Introduction, xxiv.

[4] C.C. F. Cassiano. O mercado do livro didático no Brasil do século XXI - a entrada do capital espanhol na educação nacional. São Paulo: Unesp, 2013.

[5] M. Lelis. Sistemas de ensino versus livros didáticos: várias faces de um enfrentamento. Abrale - Associação Brasileira dos Autores de Livros Educativos. Disponível em: <http://abrale.com.br/wp-content/uploads/Sistemas-ensinolivros-didaticos.pdf>, pp.2-3. (Accessed on: 20 October 2018).

[6] E. Siqueira apud C.C. F. Cassiano. O mercado do livro didático no Brasil do século XXI - a entrada do capital espanhol na educação nacional. Unesp, São Paulo, 2013, pp.308.

[7] OECD. Pisa 2015 - Results in Focus. OCDE, 2018, p.5.

[8] A. Lima and R. Catelli Jr. (Coord.). INAF Brasil 2018: Resultados preliminares. Ação Educativa/Instituto Paulo Montenegro, 2018. http://acaoeducativa.org.br/wpcontent/uploads/2018/08/Inaf2018_Relat\%C3\%B3rio-ResultadosPreliminares_v08Ago2018. pdf, (Accessed on: 20 October 2018).

[9] M. MacCullough. Filosofia Educacional. In: Fundamentos pedagógicos. ACSI, São Paulo, 2003, pp. 11-32. 
[10] R. Descartes. Discourse on the Method of Rightly Conducting One's Reason and of Seeking Truth in the Sciences. A public domain e-book.

[11] I. Kant. Critique of pure reason. Translated by J. M. D. Meiklejohn. A public domain e-book. 1781.

[12] F. Nietzsche. On truth and lies in a nonmoral sense. Oxford University Press, New York Oxford, 1989.

[13] J. W. Sire. Naming the elephant: worldview as a concept. Dando o nome ao elefante: cosmovisão como um conceito.

Tradução de Paulo Zacharias e Marcelo Herberts. Brasília-DFBrazil, Editora Monergismo, 2012.

[14] A. M. Wolters. Creation regained: biblical basics for a reformational worldview. Michigan, EUA, Wm. B. Eerdmans Publishing, e-book, 1985.

[15] J. W. Sire. Naming the elephant: worldview as a concept Dando o nome ao elefante: cosmovisão como um conceito. Tradução de Paulo Zacharias e Marcelo Herberts. Brasília-DFBrazil, Editora Monergismo, 2012, pp.179.

[16] M. MacCullough. By Design: Developing a Philosophy of Education Informed by a Christian Worldview. Colorado Springs, CO United States, Purposeful Design Publications, 2017.

[17] S. B. C. Aragão and M. H. A. Faria. "STS approach in Chemistry didactic material construction by teachers: Report of an experience with a multidisciplinary team". Indagatio Didactica, Universidade de Aveiro, Aveiro - Portugal, 8(1), July 2016, pp. 1523-1538, http://revistas.ua.pt/index.php/ID/article/view/3951/ 3634, (Accessed on: 20 October 2018).

[18] H. Dooyeweerd. A new critique of theoretical thought. Vol. 1-5. Paideia Press, USA, 1984.

[19] D. P. Ausubel. The acquisition and retention of knowledge: A cognitive view. Boston, MA, Kluwer, 2000.

[20] E. Schuurman. Fé, esperança e tecnologia: Ciência e fé cristã em uma cultura tecnológica. Editora Ultimato, 2016.

[21] M. L. Ward JR., Science is something God created humans to do. In: Biblical Worldview: Creation, Fall, Redemption. BJU Press, USA, 2017.

[22] V. S. Poythress, "Redeeming Science: a God-centered approach". Crossway Books, USA, 2006, pp.15.

[23] E. Schuurman. Fé, esperança e tecnologia: Ciência e fé cristã em uma cultura tecnológica. Editora Ultimato, Brazil, 2016.

[24] P. Spears. Introdução à filosofia, In: Fundamentos bíblicos e filosóficos da educação, ACSI, São Paulo, 2004, pp. 22-23.

[25] Brasil e Ministério da Educação, Secretaria de Educação Média e Tecnológica. Parâmetros Curriculares Nacionais ( $\mathrm{PCN}+$ ): Ciências da Natureza, Matemática e suas Tecnologias. Brasília: Ministério da Educação, 2000. http://portal.mec.gov.br/seb/ arquivos/pdf/CienciasNatureza.pdf, (Accessed on: 24 October 2016).

[26] S. B. C. Aragão. Alfabetização científica: concepções dos futuros professores de química. São Paulo, 2014. Dissertação (Mestrado) - Universidade de São Paulo. Faculdade de Educação, Instituto de Física, Instituto de Química e Instituto de Biociências.

[27] Allchin, D., Teaching Nature of Science: perspectives and resources. Minnesota: Ships Education Press, 2013.
[28] Cachapuz, A., D. Gil-Perez, A.M.P Carvalho, J. Praia, and A. Vilches. A necessária renovação do ensino das ciências, Cortez, São Paulo, 2011

[29] T. Forato, R. Martins, and M. Pietrocola, "A natureza da ciência na escola básica: enfrentando obstáculos na construção de narrativas históricas", Enseñanza de las Ciencias , Número Extra VIII Congresso Internacional sobre Investigación en Didáctica de las Ciencias, Barcelona, 2009, pp. 3241-3245.

[30] S. A. A. Martorano, M. E. R. Marcondes, "As concepções de ciência dos livros didáticos de química, dirigidos ao ensino médio, no tratamento da cinética Química no período de 1929 a 2004", Investigações em Ensino de Ciências, 14(3), 2009, pp. 341-355.

[31] F. Abd-El-Khalick, M. Waters, A. Le. "Representations of Nature of Science in High School Chemistry Textbooks over the Past Four Decades", Journal Of Research In Science Teaching, 45(7), 2008, pp. 835-855.

[32] H. Schiffer, A. Guerra, "Electricity and Vital Force: Discussing the Nature of Science Through a Historical Narrative", Science Education, 2015, pp. 409-434.

[33] L. H. Akahoshi and M. E. R. Marcondes. "Contextualização com enfoque CTSA: Ideias e Materiais Instrucionais Produzidos Por Professores de Química", Enseñanza de las Ciencias, 2013, pp. $37-41$.

[34] E. L. Silva, M. E. R. Marcondes. "Visões de contextualização de professores de química na elaboração de seus próprios materiais didáticos", Ensaio , 2010, pp. 101-118.

[35] L.H. Sasseron, A.M.P. Carvalho, "Alfabetização Científica: uma revisão bibliográfica", Investigações em Ensino de Ciências , 16(1), 2011, pp. 59-77.

[36] R.C. Suart. Habilidades cognitivas manifestadas por alunos do ensino médio de química em atividades experimentais investigativas. São Paulo, 2008. Dissertação (Mestrado) Universidade de São Paulo. Faculdade de Educação, Instituto de Física, Instituto de Química e Instituto de Biociências. 2008.

[37] U. ZOLLER, "Are lecture and learning: are they compatible? Maybe for LOCS: unlikely for HOCS", Journal of Chemical Education, 70(3), 1993, pp. 195-197.

[38] S. B. C. Aragão and M. H. A. Faria. "STS approach in Chemistry didactic material construction by teachers: Report of an experience with a multidisciplinary team". Indagatio Didactica, Universidade de Aveiro, Aveiro - Portugal, 8(1), July 2016, pp. 1523-1538, http://revistas.ua.pt/index.php/ID/article/view/3951/ 3634, (Accessed on: 20 October 2018).

[39] SME. Química. Livro 4. Coleção Escolher com Sabedoria Ensino Médio. Editora Mackenzie, São Paulo, 2016.

[40] A. Parent. "Giovanni Aldini: from animal electricity to human brain stimulation", The Canadian Journal of Neurological Science, v. 31, n. 4, Canada, November 2004, pp. 576-584.

[41] F. Abd-El-Khalick and N. G. Lederman. The influence of History of Science courses on students' views of Nature of Science. Journal of Research in Science Teaching, 37(10), 2000, pp. 1057-1095.

[42] F. Abd-El-Khalick, M. Waters, A. Le, "Representations of Nature of Science in High School Chemistry Textbooks over the Past Four Decades", Journal of Research In Science Teaching, 45(7), 2008, pp. 835-855. 